\title{
German Geopolitics in Transition
}

By: Alexander B. Murphy \& Corey M. Johnson

\section{This is an Author's Accepted Manuscript of an article published in}

Murphy, A.B. and C. Johnson (2004) “German Geopolitics in Transition,” Eurasian Geography and Economics 45(1): 1-17.

[copyright Taylor \& Francis], available online

at: http://www.tandfonline.com/10.2747/1538-7216.45.1.1.

\begin{abstract}
:
Two American geographers examine the evolution of Germany's geopolitical orientation in the aftermath of World War II, through the Cold War era, the war on terrorism, 9/ 11, and the U.S. invasion and occupation of Iraq in 2003. Drawing on public statements by German officials, government documents, opinion polls, and media accounts, the authors analyze the country's increasing post-Cold War assertiveness in foreign policy and much greater autonomy from the United States. They also evaluate the plausibility of two proposed geopolitical scenarios: that Germany will become part of a Paris-Berlin-Moscow-Beijing axis and that Germany will adopt a Europeanist, rather than Atlanticist, orientation.
\end{abstract}

Keywords: geography | Germany | geopolitical orientation | geopolitics | political history | foreign policy

\section{Article:}

The world is reorganizing itself, and this raises the question of the place and role of our country and, above all, an ever more integrated Europe. It is therefore imperative to create clarity with respect to the nature and dimensions of the challenges that face us and pursue with others the appropriate strategy.

— Joschka Fischer, 27 May 2002

\section{INTRODUCTION}

These words, spoken by Germany’s popular foreign minister, capture something of the upheaval surrounding Germany's changing place in the world. During the second half of the 20th century, Germany's geopolitical identity was clearly European and Atlanticist - reflecting the Weltanschauung of a nation preoccupied with rebuilding, rehabilitating, and reunifying itself. Its geopolitical orientation was self-reflective, cautious, and deferential. Of course, the Federal Republic played a key role in the Cold War, but the country functioned more as geographic 
staging ground than as political actor. The fall of the Berlin Wall and the crumbling of the Soviet empire did not change this state of affairs in the short term. If anything, Germany took a hiatus from world affairs for a few years, focusing its energies on the reintegration of East and West.

Fischer's choice of words, “Die Welt ordnet sich neu” (“The world is reorganizing itself”), seems to be in keeping with Germany's postwar era of geopolitical passivity. He suggests that something beyond Germany's control is happening to the world, and that Germany needs to adjust accordingly. Yet Fischer goes on to frame the issue in a manner that reflects a new assertiveness — one that began to emerge in the late 1990s and that has become more conspicuous over the past two years. Not only is Germany facing a world in transition; Fischer indicates that Germany must grapple with the role it should play in the emerging order.

By almost any indicator Germany has become a more significant global player than at any time since World War II.2 There are many reasons for this, but the fallout surrounding the events of September 11, 2001, is surely among the most important. This paper argues that German policymakers saw September 11 as an opening through which to shed the postwar yoke of geopolitical quiescence. This is not a profound observation by any means, as observers and policymakers themselves have noted (e.g., Schröder, 2002). Yet it opens up a series of important questions that are at the heart of the present analysis. What does Germany's new assertiveness portend for its geopolitical orientation? Will Germany challenge the basic Atlanticist geopolitical order that emerged after World War II?

The importance of such questions is suggested by the debate that is already emerging over them. Some commentators on German-American relations argue that a newly assertive Germany signals a sea change in the Westbindung that has defined foreign policy from the inception of the Bundesrepublik in 1949 (e.g., Daalder, 2003). Robert Kagan goes so far as to argue that the United States and Europe are headed down fundamentally divergent paths, and that a Europe under Franco-German leadership will increasingly oppose the United States in the international arena (Kagan, 2002). Others foresee an even larger-scale geopolitical reorientation, speculating about the emergence of a new Paris-Berlin-Moscow-Beijing axis that could function as a global counterweight to the United States (Ross, 2003).

This paper assesses the plausibility of these scenarios against the backdrop of geopolitical changes that have unfolded in and around Germany over the past two years. Drawing on public statements by German officials, official documents, newspaper accounts, and opinion polls conducted in Germany, the article documents the stresses that have emerged in the transatlantic partnership between Germany and the United States. Yet these sources also show the resilience of transatlanticism, as well as important continuities in Germany's role in Europe. We thus conclude that Germany's geopolitical transition is more a matter of evolution than revolution.

Our sketch of German geopolitics begins with a background section explaining our use of the term "geopolitics" and examining the period leading up to the September 11 terrorist attacks. We 
then look at the post-September 11 era, which began with declarations of "unlimited solidarity" with the United States, but culminated in a very public airing of grievances over the American invasion of Iraq in the spring of 2003. We conclude by taking up the question of what the postAmerican-invasion-of-Iraq era portends for Germany’s geopolitical orientation.

\section{BACKGROUND}

\section{Geopolitics in Theory and Practice}

Linking Germany’s changing international role to "geopolitics” might seem curious, given the history of the term. The intellectual roots of geopolitics as a concept can be traced to the 19th century efforts of the German geographer Friedrich Ratzel and the Swedish political scientist Rudolf Kjelleln to explain the territorial dynamics of state growth. Its subsequent appropriation by the Nazis - particularly in the context of the school of geopolitics that developed around Karl Haushofer-gave it a distinctly checkered history (Agnew, 2003). Indeed, for a time geopolitics was so closely identified with German expansionism in the 1930s and 1940s that it became almost taboo to use the term. As a result of this history, prominent commentators continue to argue that "geopolitics" should be used with extreme caution (Bassin, 2003).

Over the past 15 years, however, the term has come into increasing use in the wake of the collapse of the post-World War II order. A revival of interest in geopolitics emerged as part of the effort to explain and analyze the sweeping changes that came about in the wake of the disintegration of the Soviet Union, the reunification of Germany, and the shift from "European Community" to "European Union.” These developments led to a fundamental reworking of the perceptual and functional organization of power that dominated during the Cold War era. "Geopolitics" captured something of this reworking, given its twin emphasis on the political organization of space and more amorphous ways in which power is arrayed across the surface of the earth.

Notably, most contemporary scholarship on geopolitics has nothing in common with the geopolitics of Haushofer. Rather than seeking to advance the territorial interests of a particular state, the study of geopolitics is now focused on the attempt to understand why particular geopolitical views and arrangements emerge, as well as their consequences (e.g., Ó Tuathail, 1996). This is the spirit in which we deploy the term in this paper. We proceed from the idea that government policies and practices reflect particular understandings of a state's position in the global power matrix, as well as ideas about how that position might or should change over time. These geopolitical understandings and ideas can have important consequences; hence, it is important to analyze them if we are to gain insight into larger shifts in the global geopolitical landscape.

German Geopolitics in the Cold War Era 
Any understanding of the changing face of contemporary German geopolitics must begin with the template that was established in the wake of World War II. Positing a template can be problematic, as there is always a range of views at play at any time and in any place. Consensus did not exist even in postwar West Germany, where the overarching desire to distance the country from its Nazi past promoted more uniformity than in most countries (Ossenbrügge, 1989). Nonetheless, certain geopolitical visions tend to dominate policymaking during particular periods, and this is certainly true for the Bundesrepublik for several decades after its establishment in 1949.

The curious feature of postwar German geopolitics is that it was grounded in the rejection of an explicit geopolitical vision. Instead, the country sought to carve out its role in the world based on its economy. Foreign policy was largely designed to facilitate private-sector efforts to build and maintain markets for the output of the Wirtschaftswunder, while strictly avoiding any pretense of political-territorial ambition (Hanrieder, 1989). The only significant exception was the effort to leave open the possibility of German reunification, as represented by the Ostpolitik of Willy Brandt.

Of course, an avowed rejection of geopolitics does not mean that certain geopolitical ideas do not hold sway. Neil Smith's (2003) study of the United States during the first half of the 20th century shows that the country's economic extension of power was very much a product of a certain geopolitical weltanschauung. Similarly, one could say that the focus on economics in postwar Germany reflected a certain geopolitical view-albeit one that was quite different from that which prevailed in the United States. The German view was rooted in the idea that Germany needed to atone for its past, act as a peaceful participant in the global community, and find its way forward through a policy focused on economic revival (Ash, 1993).

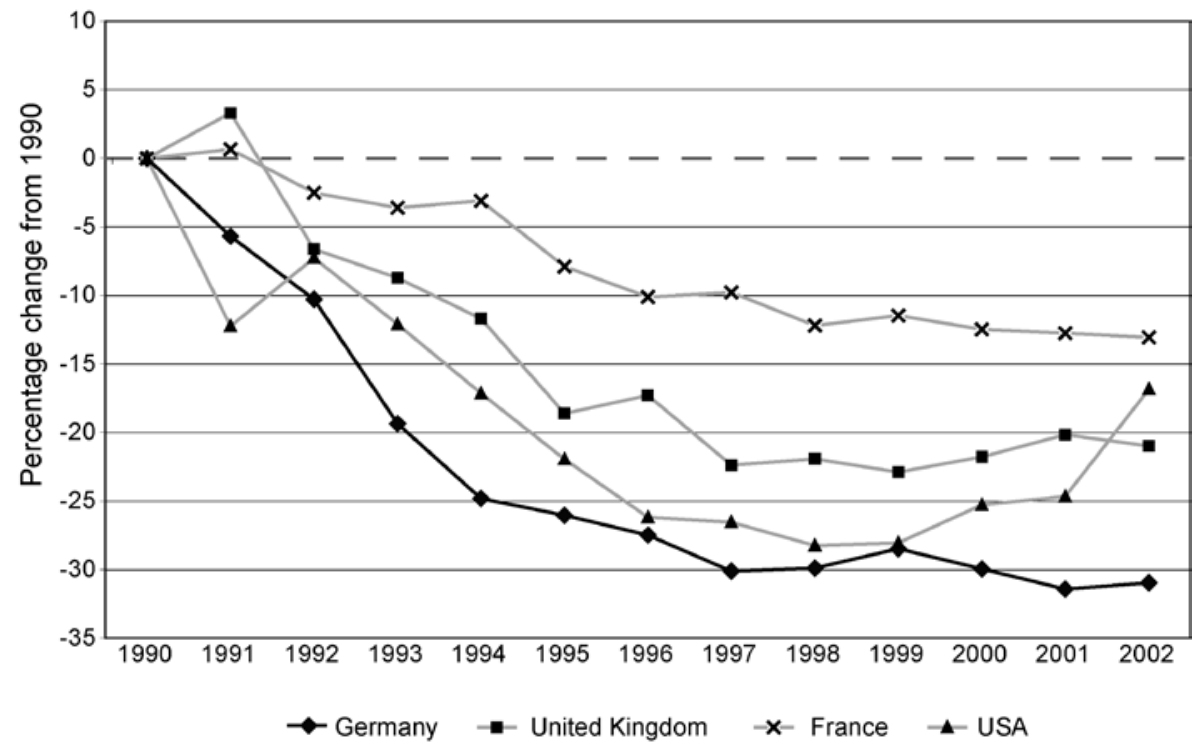


Fig. 1. Military spending since the Cold War. Percentage change from base year $(1990=0)$ calculated by authors in U.S. dollars at constant prices and exchange rates in the year 2000. Source: Authors' calculations from data in SIPRI (2003). Permission to use the SIPRI data was granted on November 26, 2003.

The main features of postwar Germany’s foreign policy reflect these goals. The country eschewed any pretense to the external projection of political or military power, although the concern with atonement found expression in strong support for Israel. Germany also committed itself completely to the postwar territorial settlement that took hold in Europe, while seeking to keep communication channels open to the East in the hope of reuniting the German nation. Finally, and most importantly, Germany tied itself economically, politically, and culturally, to the West. Westbindung was almost an orthodoxy, leading Germany to adopt a strong Atlanticist orientation and to become a champion of European integration (Jones, 1994).

The 1990s

German reunification in 1990 occasioned a reassessment of the country's role in the world. As the Cold War ended, and as the financial burdens associated with reunification became more onerous, Germans turned their sights inward. Indicative of Germany’s disinterest in playing an active external geopolitical role, military spending was cut dramatically (International, 1991). Many countries sought to cash in on the "peace dividend" afforded by the end of the Cold War, of course, but few more than Germany (Fig. 1). The country reduced military expenditures by 2000 to around 1.5 percent of its GDP, approximately where it stands today (International, 2003).

Even as Germany’s military capacity was being cut, events in the Balkans began to challenge the country's external geopolitical disengagement. The conflicts surrounding the break-up of the former Yugoslavia in the early to mid-1990s provided a stark reminder that diplomacy could not always stop bloodshed. Moreover, as the Milosevic regime turned to policies that smacked of "ethnic cleansing," Germany found itself facing a situation in its own backyard that resonated with its own Nazi past (Deckers, 2002). Under the circumstances, Germany staked out an uncharacteristically visible posture on the break-up of Yugoslavia, being the first country to recognize the independence of Croatia and Slovenia and challenging the one-Yugoslavia policy that seemed to hold sway in other parts of the Western alliance (Deckers, 2002).

Germany’s growing assertiveness over the Balkan situation signaled an important shift in the country's overt geopolitical orientation, but it did not represent any real break from the postwar template. Germany sought to advance its position within the context of the Western alliance, and the circumstances surrounding the break-up of Yugoslavia permitted it to take a position that was entirely consistent with the continuing effort to atone for past wrongs (Krieger, 1994). Yet it also 
set the country on a course that could lead to greater German geopolitical assertiveness. The Kosovo crisis in 1999 provided the context for exactly that.

The situation in Kosovo unfolded shortly after a new Red-Green government came to power in Germany. Shocked at the massacre of ethnic Albanians that was going on there, newly elected Chancellor Gerhard Schröder argued that the rhetoric on the importance of human rights and basic freedoms employed by German diplomats around the world would lose credibility unless Germany was prepared to stand up for those values a few hundred kilometers from its own border (The Washington Post, April 18, 1999, p. B1). Against this backdrop, the German government made the decision to deploy troops outside its own territory for the first time since World War II.

Kosovo set at odds Germany’s post-war credo of pacifism—nie wieder Krieg (never again war) — with its vision of human rights for all peoples—nie wieder Ausschwitz. This is reflected in an April 1999 Regierungserklärung (statement of government policy):

To simply stand by and watch [Milosevic's murderous actions] would have been cynical and irresponsible. NATO must react to escalating violence. Our experience in Croatia, Bosnia and Herzegovina, where there were more than 200,000 victims of war, shows that waiting patiently by would have made us Europeans once again guilty. NATO is a community of values. Together with our partners we are fighting in Kosovo for our values. For human rights, freedom and democracy. [...] Do we as Europeans want to allow in the 21st century, in light of our experiences with two ghastly wars in this century, that dictators in the center of Europe are permitted to ravage? (Bundesregierung, 1999).

Certainly for the Schröder government, Kosovo represented a significant moral issue as well as an opportunity for Germany to adopt a geopolitical stance that was more in keeping with the actions of a "normal nation.”3

As the 1990s gave way to the 21st century, Germany seemed to be charting a new course, albeit one that was firmly entrenched within the basic framework of the country's postwar geopolitical template. At the same time, a change of administration in Washington, DC, introduced a new dynamic to the trans-Atlantic partnership that was at the heart of Germany's

Westbindung. A variety of initiatives during the first months of the Bush presidency raised questions in Germany about the commitment of the United States to the transatlantic alliance. Within a few months of being elected, the Bush administration distanced itself from the Comprehensive Test Ban Treaty, the International Criminal Court, and the Anti-Ballistic Missile Treaty_all with little consultation with its traditional European allies (Hoagland, 2001). Moreover, the United States rejected the Kyoto Accord on global warming, an accord that the Schröder government had specifically sought to advance. The symbolism of President Bush declaring the Kyoto treaty “dead” during a March 2001 visit by Gerhard Schröder was not lost 
on Germans. The event was seen as a major embarrassment for Schröder back home and a signal of the turbulence that lay ahead for the bilateral relationship (The Wall Street Journal, April 6, 2001, p. B7).

The severity of the transatlantic rupture was highlighted when the prominent editor of Die Zeit, Josef Joffe, posited the emergence of a trans-Atlantic "Kulturkampf” in February (Joffe, 2001a). Moreover, German (and other European) politicians began to chastise the U.S. for abandoning its commitments to multilateral governance structures and for stepping back from the Middle East peace process. Trade relations too were worsening thanks to disputes over bananas, genetically modified organisms, and steel (Hoagland, 2001). Hence, with September 11, 2001, just around the corner, there were signs of serious strains in the transatlantic alliance. Few suggested that Germany was prepared to move away from its Atlanticist geopolitical orientation, but questions of Germany’s relationship with the United States were clearly “on the table.”

FROM SEPTEMBER 11, 2001, TO THE INVASION OF IRAQ

Unlimited Solidarity

The responses of the German public and government to the September 11, 2001, terrorist attacks in the United States created a very real, if short lived, sense of renewed transatlantic unanimity. To a gathering of 200,000 people in front of the Brandenburg Gate three days after the attacks, Federal President Johannes Rau evoked the symbolic importance of the gate standing behind him for post-World War II relations. He assured America that Germans were at the side of their ally to whom they were bound "by friendship ... by the same values ... [and] by our love of freedom” (Rau, 2001). The catchphrase uneingeschränkte Solidarität (“unlimited solidarity”), offered by German officials at every public forum, was accompanied by tangible offers of assistance to the U.S. in the form of intelligence and police force cooperation and Germanmanned AWACS aircraft patrolling airspace along the American Eastern Seaboard (The Washington Post, November 19, 2001, p. A3). Ultimately, Germany expressed a willingness to extend its military engagements outside of Europe, sending forces to participate in the US-led initiative to topple the Taliban in Afghanistan (The Washington Post, October 12, 2001, p. A24).

Germany’s reaction to 9/11 reflected horror at the nature and scale of the attack, as well as a certain amount of guilt that the attacks had been at least partially hatched in Hamburg (Joffe, 2001b). As already noted, the period leading up to September 11 was increasingly defined by transatlantic squabbling. The response by Germany to the terrorist attacks was therefore intended, at least in part, to reinvigorate relations with the United States and to demonstrate Germany’s transatlantic credentials to the wounded superpower.

But German policymakers also saw September 11 retrospectively as an opportunity to (re)define Germany’s role in the world. In his successful 1998 campaign to unseat Helmut Kohl, Gerhard Schröder argued that it was time for Germany to become "a normal nation again” in foreign affairs (Walker, 2001). September 11 was viewed as a chance to make good on that campaign 
promise and to shed the reputation of Germany as an economic giant and political dwarf.4 Statements by German officials in the month following the attacks give an indication of how Germany wished to define its role both as an ally of the United States ("unlimited solidarity") and as a sovereign power within a unified Europe. That those two goals might eventually come into conflict with one another was not yet recognized.

Germany's willingness to commit military forces in Afghanistan was a potent symbol of the nation's renascent engagement in security affairs outside of Europe. Even as some in the U.S. complained that President Bush waited too long to pursue military action against the Taliban government, for Germans the pace of events was dizzying, requiring that post-war soul-searching be compressed into a matter of weeks.5 Afghanistan marked Germany's first combat causalities since World War II. It was, in the words of Wolfgang Ischinger, the German ambassador to the United States, the first time German soldiers have been on the "right side of a war" in over 100 years (Ischinger, 2002).

In fact, Germany's solidarity was conditional more than unlimited. Joschka Fischer acknowledged the unmistakable reality that September 11 "rocked America much harder than Europe," and that Americans would be more willing to pursue the war on terrorism wherever it led (Fischer, 2002a). This political reality in turn shaped Germany's evolving solidarity with its ally: If the United States pursued its war on terrorism under the auspices of multilateral institutions, then September 11 would begin a new era of multilateralism to which Germany would be fully committed. If, on the other hand, the United States unleashed its wrath unilaterally, without the blessing of the United Nations, Germany's solidarity would be anything but unlimited. This position was hinted at just two weeks after the attacks. In the words of the German ambassador: “(W)ouldn’t it make sense if terrorists and their sponsors could be brought to justice before an internationally recognized criminal court?" (Ischinger, 2001).

Germany's position was further spelled out in a speech at the United Nations by Joschka Fischer two months after the terrorist attacks in New York and Washington. In the hope of promoting a multilateral course, Fischer claimed that

A new coalition has arisen. It now must be strengthened and expanded into a true partnership. If we are successful in this, then history may view September 11 not just as a horrific day for humanity, but also as the beginning of a new era of cooperation and multilateralism. (Fischer, 2001)

Fischer also laid out Germany's preferred course with respect to Iraq's weapons of mass destruction: the world community should focus on "nonproliferation and global disarmament" (ibid.).

Major speeches by German officials after September 11 underlined the degree to which Germany sought to become a "normal nation" again. For Germany, the fight against terrorism was an opportunity to engage the world community in a discussion of the issues that underlie terrorism: 
global inequity, unsustainable development, the legacy of colonialism in the Middle East and Southwest Asia, and the ripple effects of the continuing conflict between Israelis and Palestinians (Bundesregierung, 2001). In Germany’s view, a United States firmly engaged in "cooperation and multilateralism” was absolutely critical to any serious effort to confront these issues.

Lead-up to the Invasion of Iraq

If Germany was reluctant to challenge the United States in the immediate aftermath of September 11, such reticence ended by early 2002. The government attempted to distance "unlimited solidarity" from a U.S. policy that seemed to be headed in an increasingly confrontational direction. Within a matter of weeks of George W. Bush's 2002 State of the Union address, Foreign Minister Fischer made clear that, in an alliance of sovereign democracies, Germany would not simply follow the leader ("Alliance partners are not satellites.”) (Fischer, 2002b). His comment reflected not only discomfort among German politicians with the alleged “Axis of Evil” (Iraq, Iran, North Korea), but also increasing frustration with American unwillingness to share intelligence or declare enemy combatants being held in Guantanamo Bay as prisoners of war in line with the Geneva Conventions (The New York Times, January 24, 2002, p. A1). Germans felt underappreciated for their role as the second largest provider of troops in Afghanistan and underconsulted in the ongoing war on terrorism (The New York Times, September 12, 2002, p. B1).

In response to the strains that emerged in the transatlantic bond, leaders in Berlin focused attention on the effort to forge a European Security and Defense Policy (ESDP) and a Common Foreign and Security Policy (CFSP) within the context of the European Union. In Berlin's view, these initiatives would enable Germany and Europe to take an independent approach to global security. At the same time, Germans were cognizant of the fact that, as Joschka Fischer related, the European Union was "not constructed for war and peace” and that "nation-states” would continue to play central roles in the formation and execution of foreign policy (Fischer, 2003a; see also Walker, 2001). The subsequent discord within the European Union over Iraq clearly highlighted the veracity of this observation.

All of this signaled a further assertiveness in German foreign policy, as well as the country's increasing discomfort with a geopolitical template that cast German interests firmly within the context of U.S. priorities. Indicative of Germany's assertiveness was its vigorous effort to secure permanent status on the United Nations Security Council after September 11, 2001 (The Financial Times, May 22, 2002, p. 12). In addition, during the months leading up to the U.S. invasion of Iraq, Germany used its rotating seat on the Council to assert, more forcefully than ever before, its own position. 6

During the 2002 election in Germany, Chancellor Gerhard Schröder campaigned on a platform that included outright rejection of U.S. policy toward Iraq (Larres, 2003). The success of the campaign highlighted the degree to which the German public rejected the country's longstanding 
geopolitical stance vis-à-vis the U.S. Indeed, the United States' invasion of Iraq represented an effective end to the post-9/11 period of "common purpose" in the war on terror between Germany and the U.S. In stark contrast to the era of “unlimited solidarity," by early 2003 the German weekly Die Zeit labeled Transatlantiker an endangered species in Germany (Ross, 2003). Even if this can be attributed in part to a soured personal chemistry between President Bush and Chancellor Schröder in the wake of a hard-fought German election campaign, one must also recognize that much has changed between the Bundesrepublik and the United States since the Cold War days of almost reflexive deference.

The German Marshall Fund's Transatlantic Trends survey shows the degree to which the German public was becoming increasingly uneasy with their country's geopolitical relationship with the United States (German, 2003). Figure 2 indicates that the lead-up to the U.S. invasion of Iraq coincided with a dramatic shift in President Bush's approval rating in Germany and a corresponding shift in German support for U.S. leadership in the world. By 2003, fully 70 percent of Germans wanted to see the European Union become a superpower that could act as a counterweight to the United States. The latter view rings a bit hollow given the lack of corresponding support for increasing military spending, but it is indicative of a significant shift in the German geopolitical imagination.

For all the import of these developments, the ties that bind the United States and Germany are numerous and are not easily sundered. NATO is still the bedrock on which Germany's_-and Europe's - security guarantees are built. Absent the establishment of a European military force wholly separate from NATO - an unlikely proposition in the short term given opposition to increased military spending - it will be very difficult to forge a German geopolitical posture that is truly independent of the United States. Moreover, the economic, social, and cultural ties between the United States and Europe are extensive. Finally, there is considerable inertia behind the geopolitical template established after World War II. The set of institutions, practices, and contacts established at that time clearly helped to keep the transatlantic rift within bounds (Gordon, 2003). Nonetheless, the lead-up to the U.S. invasion of Iraq represented a significant challenge to Germany's geopolitical orientation, paving the way for an unprecedented reassessment of Germany's role in the world.

\section{IMPACTS OF THE IRAQ INVASION}

The U.S.-led invasion of Iraq on March 20, 2003, represented a direct challenge to Germany’s call for multilateralism. American and coalition troops entered the country without a clear Security Council mandate, and just 43 days later President Bush declared "major combat operations” at an end. Once fighting had begun, rhetoric from Berlin shifted from unconditional rejection of the U.S. action to an articulation of Germany's wish for a swift end to the conflict (Bundesregierung, 2003). With public opinion in Germany aligned strongly against the United States, German leaders were careful not to sound supportive of the U.S. initiative, but to the 
surprise of some they also seemed anxious not to exacerbate the wounds that had opened in the transatlantic relationship in the lead-up to March 2003.

In a speech two weeks after the Iraq war began, Chancellor Schröder captured the quandary facing Germany with respect to Iraq (Bundesregierung, 2003). While lamenting both Europe’s inability to arrive at a consensus on Iraq and the broader failure of multilateralism, Schröder advocated a quick end to the conflict and made clear on whose side Germany stood. Minister Fischer expressed his support in another way: "Saddam Hussein is gone. There is always cause for rejoicing when dictators fall” (Fischer, 2003b).

\section{Germany}

In thinking about international affairs, which statement comes closer to your position about the United States and the European Union?
Do you approve or disapprove of the way U.S. President George Bush is handling international policy?

How desirable is it that the United States exert strong leadership in world affairs?

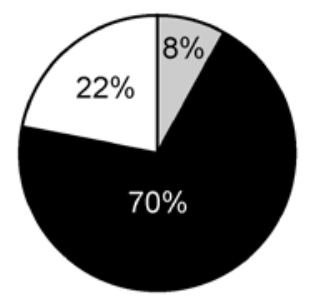

-EU should become a superpower

$\square$ U.S. should remain the sole superpower

\section{$\square$ Other}

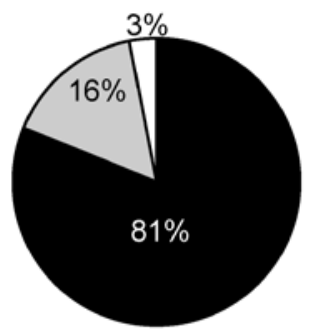

Disapprove/undesirable $\square$ Approve/desirable 口Other
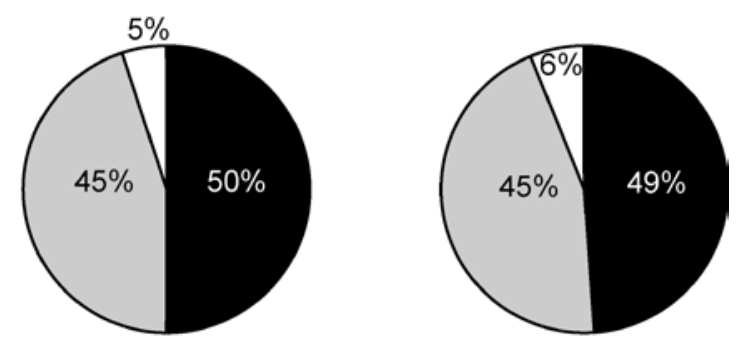

Disapprove/undesirable $\square$ Approve/desirable 口Other
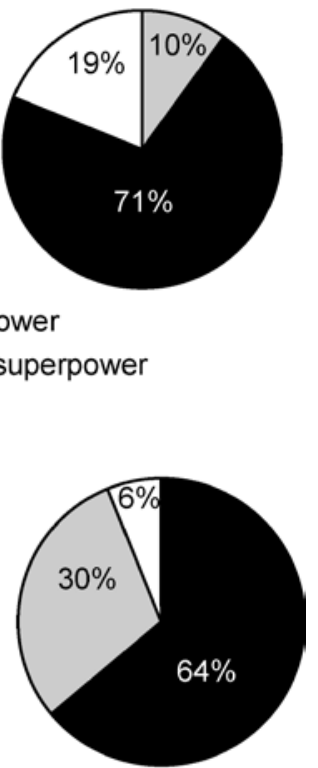
Even as polls confirmed the German public's profound opposition to war in Iraq, diplomats sought to restore civil dialogue between Chancellor Schröder and President Bush. Relations between the two had been icy ever since Schröder declared his opposition to the Bush administration's Iraq policy during a hard-fought campaign the previous fall.7 It was not until September 2003, at the United Nations General Assembly, that Bush and Schröder had their first substantive one-on-one dialogue. The two leaders offered contrasting views of the Iraq situation, but they both seemed anxious to maintain constructive and continuing dialogue (The Boston Globe, September 25, 2003, p. A16). Indeed, the meeting seemed to undercut the assertion of a high-ranking White House official, who argued that there no longer existed among Europeans "the basic feeling of good-will towards America that dominated for decades" (Handelsblatt, November 20, 2003 [http://www.handlesblatt.de]).

On the second anniversary of the terrorist attacks on New York and Washington, an interviewer asked Foreign Minister Fischer how the attacks would be viewed by history 20 years out. Would the U.S., after an exceptional period of "escapades" in places like Iraq, return to the multilateral order it had established after World War II? Fischer responded:

The word "escapades" is simply false. There was strategic dissent on the Iraq question. But a world of 6 billion people will be multilateral. The "empire" debate strikes me as distant from reality for two reasons. The U.S. is a large country, that has interests in the world but is also inward looking, and most Americans do not want to be an imperial nation. Second, even the U.S., as matchless as its power is in world history, is not powerful enough to establish global order alone. (Fischer, 2003c)

This statement, which was both conciliatory and reaffirming of Germany's commitment to multilateralism, was repeated by others as well, including Schröder (2003a, Voigt, 2003).

In an effort to bring transatlantic relations back to a modicum of stability, Germany's foreign policy establishment went so far as to consider committing troops to the post-war stabilization effort in Iraq (Diehl, 2003). This option eventually was rejected; Germany instead offered to train Iraqi police officers. Moreover, at a donors' conference in Madrid, Germany declined to add to the $\$ 224$ million it had already committed to the postwar reconstruction of Iraq (The Los Angeles Times, October 23, 2003, p.10).8 Germany's leaders had little choice; a November 2003 Eurobarometer poll showed that 84 percent of Germans (more than in any other EU member state) thought the United States should finance the rebuilding of Iraq (European Commission, 2003). Nonetheless, the U.S.-led invasion of Iraq did not lead to a worsening of the transatlantic relationship in the short term. If anything, there is more dialogue now than there was in the leadup to the invasion.

\section{ASSESSING THE CURRENT SITUATION}

Why did the U.S. invasion of Iraq not signal a further deterioration of the U.S.- German relationship? The answer seems to lie in the forces working against a fundamental reorientation 
of Germany’s geopolitical Weltanschauung. As noted at the beginning of this article, two reorientation scenarios have been suggested for Germany: a radical shift in the direction of a Paris-Berlin-Moscow-Beijing axis and a more modest shift toward a Europeanist orientation that defined itself in opposition to the United States. An assessment of Germany's current situation suggests that the first of these scenarios is highly unlikely, and that even the second one is improbable_-at least in the near term.

Turning to the first scenario, an extensive review of statements by German political and diplomatic figures reveals nothing that hints at a German effort to configure its interests in terms of a Paris-Berlin-Moscow-Beijing axis. To the contrary, the European Union and the transatlantic relationship are stressed repeatedly as the cornerstones of German foreign policy by spokespersons for both the ruling coalition and the opposition parties. Of course, relations with Russia are important to Germany for a variety of reasons, and academics and political figures alike have questioned where Europe’s eastern border should lie. To quote Joschka Fischer:

Europe is in the West, together with the United States and Canada. There is no doubt about that [...] But Europe has a problem in determining its eastern border. Right from the start this demarcation has been more or less cultural or arbitrary. Europe has clear boundaries to the north, west, and south. But to the east we are part of the Eurasian continent, a fact which is reflected in the difficult debate about enlarging the European Union. (Fischer, 2003d)

Fischer's musings about Eurasian geography suggest that Germany is increasingly conscious of its position in relation to lands to the east, but they do not suggest that Germany is seeking to realign itself with Moscow. To the contrary, Germany’s growing ties with incoming EU countries, especially Poland, may well work against a closer relationship with Moscow. In addition, as thorny as managing America’s “hyperpower” may seem for European leaders, Russia is hardly a tempting alternative in its present state. Germany views its role vis-à-vis Russia as cultural interlocutor with the rest of the West; any geopolitical advantage to working with Russia tends to be viewed in the context of European relations and its potential impact on the transatlantic partnership.

As for German abandonment of transatlanticism in favor of a Europeanist geopolitical posture, Robert Kagan (2002) suggests that the immediate aftermath of September 11, 2001, was a fleeting moment of solidarity between erstwhile allies, but that the larger trend is toward transatlantic divergence. According to Kagan, this divergence is based on a pessimistic, Hobbesian America that views awesome military superiority as the only feasible way to manage the risks posed by unwieldy state and non-state actors. Europe, meanwhile, has resigned itself to its own military impotence, and its members pursue cooperation, multilateralism, and humanitarianism as foreign policies under the convenient umbrella of American military protection-compliments of NATO. 
Germany is the European Union's largest economy; along with France, it is the driving force behind the move towards greater political integration. Hence, Germany presumably embodies the "Europe" that is depicted in Kagan's article and subsequent book (Kagan, 2002, 2003). Yet the German case casts considerable doubt on his effort at geopolitical foreshadowing. Germany does not fit the Kagan mold now; for example, in recent years it has become more, rather than less, willing to project its military power. Moreover, there is much that works against Germany's abandonment of its transatlantic orientation.

At least three features of the contemporary geopolitical scene argue against a German geopolitical reorientation along the lines suggested by Kagan. The first of these arises out of the interconnections and shared values that link Germany and the United States. The interconnections are easiest to quantify: they include trade, business partnerships, school exchanges, even American military personnel who have lived for an extended time in Germany (e.g., Colin Powell). Especially older Germans remember American magnanimity in the form of the Marshall Plan aid and the Berlin Airlift (Larres, 2003). Moreover, many Americans claim some percentage of German heritage, although it is an open question whether this is as important to bilateral relations as is suggested by its frequent invocation in statements of German and American diplomats. Collectively, however, these circumstances create an extraordinary level of interpenetration between the two countries. Cultural trade should not be overlooked in this either. Not only are American films and music still very popular throughout Europe; the flow in the opposite direction has increased in recent years from Germany, with Tom Tykwer (among other directors) finding a niche in the American cinema market.

The values side of the equation is more amorphous, but the effort to invoke these was clearly reflected in a May 2003 speech of the German Chancellor to the American Chamber of Commerce on the occasion of its 100th anniversary:

Together we are committed to international legality and, in supra-national alliances such as the United Nations, pursue the goals of liberty, democracy, and human rights, as well as free trade, shared wealth and sustainable development for all peoples. [...] Controlled disarmament and the non-proliferation of weapons of mass destruction are key points of our canon of common values. (Schröder, 2003b)

This speech was arguably part of the German government's effort to put transatlantic relations back on track after the invasion of Iraq. Of course, many Europeans/Germans are skeptical of the level of America's commitment to the United Nations, but avowals of a shared commitment to democracy and human rights have led Germany to participate alongside the United States in engagements in Kosovo and Afghanistan. Moreover, Germany has indicated its continued commitment to future initiatives of this sort as long as intervention is vindicated by democratic consultation among a broad coalition (Schröder, 2003c). The ideological partnerships reflected by these initiatives may not attract as much press as disagreements over Iraq, but they clearly work against a fundamental break in transatlantic relations. 
The lack of a consensus within the EU on military matters is a second feature of the current scene that works against a dramatic readjustment in Germany's geopolitical orientation. Indeed, Germans readily concede that the European Union is not built for resolving questions of war and peace. As Foreign Minister Fischer recently indicated, "Whether or not Germany sends troops is up to the Bundestag, not someone in Brussels” (Fischer, 2003c). That does not mean that

Germans or Europeans are content with the current division of labor in security issues. Just as no one in 1945 would have predicted open internal borders in Europe or a common currency by the turn of the century, nothing precludes Europe from adopting common defense and security policies.9 Yet clear differences exist among European states in this arena (Melloan, 2003), and they are unlikely to be resolved in the near future. Kagan, of course, views this as symbolic of the transatlantic divide. What he fails to take into consideration, however, is that the desire of some European states, including Germany, to play an active role in international affairs works in the interests of transatlanticism. At least in the short term, there is no viable Europeanist alternative.

The third geopolitical circumstance that works against a fundamental reorientation of German geopolitics concerns the United States itself. Following Kagan, part of the explanation for the growing divide between the U.S. and Europe/Germany is America's increasingly Hobbesian, interventionist posture. Yet it is not at all clear that most Americans want to see the U.S. in these terms. In fact, it would be an ironic role reversal if the U.S. became the fatalistic, pessimistic Hobbesian power player, while Europe assumed the role of the supremely naïve optimist. Americans were overwhelmingly supportive of the war in Afghanistan in part because it was pursued in consort with a broad coalition of allies and sanctioned by the United Nations (The Washington Post, December 21, 2001, p.A28).10 This is in marked contrast to the split in public opinion that developed over the Iraq initiative (The Los Angeles Times, November 21, 2003, p. 1). Multilateralism has obvious costs in efficiency terms, but contrary to Kagan's assumption it is not at all clear that American taxpayers are prepared to "foot the bill" for an increasingly Hobbesian, interventionist U.S. Seen in this light, U.S. multilateralism is important for pragmatic as well as ideological reasons. To the extent that Americans recognize this, a principal catalyst for a radically altered German geopolitical stance will be undermined.

\section{CONCLUSION}

German geopolitics is clearly in a time of transition. The combination of German reunification and the waning shadow of the Nazi era has opened the door to growing German assertiveness in foreign affairs. At the same time, continued progress toward European integration has focused attention on Europe, and by extension Germany, as an increasingly important geopolitical node. In addition, the past few years have seen the development of unprecedented tensions between the United States and Germany in the wake of the foreign policy split between U.S. President George Bush and German Chancellor Gerhard Schröder. 
Under the circumstances, Germany's geopolitical orientation is no longer driven by the norms that characterized the Cold War era: reflexive deference to the U.S., a complete dismissal of foreign military engagements, and disinterest in promoting a military role for the European Community (now European Union). Chancellor Schröder captured an important dimension of Germany’s new position in a recent interview aimed at the American public.

(W)e regained our full sovereignty as a country through the unification of the two German states. This entails rights and responsibilities: responsibilities, obviously, arising form being a member of an alliance, and, therefore not calling military participation and military action a taboo [...] but the right also to differentiate, to say "yes” if you think it's right, but also to be able to say "no” if you really do not think so. (Schröder, 2003c)

For all the magnitude of the change suggested by the foregoing quotation, the evidence to date suggests that change is incremental, not radical. Despite German opposition to the U.S. invasion of Iraq, the transatlantic rift has not noticeably widened since March 2003. Indeed, Germany has gone to considerable effort to reaffirm its commitment to the basic international organizational and institutional matrix that emerged after World War II. Moreover, there is much that works against a sweeping reorientation of Germany's geopolitical priorities, including the depth and inertia of transatlanticism and the difficulty of forging a viable European-focused alternative.

None of this is meant to suggest that greater shifts could not occur over the longer term. A key variable will be the trajectory of European integration, which in time could provide a foundation for a more coherent European foreign policy, at least among a core set of countries. Yet the most significant variable is likely to be the direction of U.S. foreign policy. If the United States pursues an increasingly unilateralist approach in its "War on Terrorism" and turns ever farther away from the international organizations and treaties that came to define the post-World War II international order, Germany’s foundational commitment to multilateralism will come increasingly into conflict with its transatlantic orientation. Under those circumstances, the evolutionary character of German geopolitics could indeed become revolutionary.

\section{Notes}

1 Respectively, Professor of Geography and Rippey Chair in Liberal Arts and Sciences [abmurphy@uoregon.edu], and Graduate Student [cjohns11@uoregon.edu], Department of Geography, 1251 University of Oregon, Eugene, OR 97403-1251. The senior author currently is the President of the Association of American Geographers.

2 German troops are currently participating in operations in Kosovo, Bosnia-Herzegovina, Macedonia, Georgia, Afghanistan, and the Horn of Africa (Bundeswehr, 2003). German diplomats, most visibly Foreign Minister Joschka Fischer, are actively participating in efforts to bring about peace in the Middle East and increasing dialogue with Iran. 
3 An opinion poll in Der Spiegel in March 1999 showed that a mere 19 percent of Germans favored using German troops in Kosovo (The Washington Post, October 12, 2001, p. A24).

4 In a speech before the Bundestag on 11 October 2001, Chancellor Schröder declared: "Only ten years ago, no one would have expected more from Germany than 'secondary assistance'i.e., infrastructure or funds, in the international efforts to safeguard freedom, justice, and stability. As I pointed out immediately after 11 September, this era of German post-war politics is over once and for all” (Schröder, 2001).

5 Logistically, the pace may have been too quick for the Bundeswehr (armed forces), which required Turkish assistance transporting troops to Afghanistan. This incident, embarrassing for the German government, raised concerns in Europe as to how a European rapid-reaction military force was to respond without suitable transport mechanisms.

6 Given the presence of two other European powers as permanent members on the Security Council, and Russian uneasiness with another NATO member on the council, Germany may have to make its mark on world affairs through other venues in the near term.

7 Indeed, relations between the two countries had reached a post-World War II nadir, symbolized by U.S. National Security Advisor Condoleezza Rice’s: "Punish France, isolate Germany, forgive Russia” (Applebaum, 2003).

8 Compounding the reluctance of Germany's public to support the Iraq war by contributing financially on the same order of magnitude as Germany had in Afghanistan and the Balkans, the current domestic fiscal situation in Germany makes new foreign obligations highly unlikely in the near term (European Commission, 2003).

9 European publics are broadly supportive of the goal of becoming more powerful and unified on security and defense issues (German, 2003).

10 As in the Balkans, the costs of rebuilding and conducting ongoing security operations in Afghanistan are being shouldered in significant part by European governments (The Houston Chronicle, September 29, 2002, p. 3).

\section{REFERENCES}

Agnew, John, Geopolitics: Re-visioning World Politics, second ed. London, UK and New York, NY: Routledge, 2003.

Applebaum, Anne, “Memo to Bush: Europe is Listening,” The Washington Post, May 28, 2003, A19.3.

Ash, Timothy Garton, In Europe’s Name: Germany and the Divided Continent. New York, NY: Random House, 1993. 
Bassin, Mark, "Between Realism and the 'New Right': Geopolitics in Germany in the 1990s," Transactions of the Institute of British Geographers, 28, 3:350-366, September 2003.

Bundesregierung (Federal Government of Germany), Regierungserklärung von Bundeskanzler Gerhard Schröder zur Aktuellen Lage im Kosovo (Statement of Government Policy by Chancellor Gerhard Schröder on the Current State of Affairs in Kosovo). Bonn, Germany, April 14, 1999 [http://www.bundeskanzler.de/Regierungserklaerung-.8561.htm].

Bundesregierung (Federal Government of Germany), Regierungserklärung von Bundeskanzler Schröder zur aktuellen Lage nach Beginn der Operation gegen den internationalen Terrorismus in Afghanistan (Statement of Government Policy by Chancellor Schröder on the Current State of Affairs following the Beginning of the Operation against International Terrorism in Afghanistan). Berlin, Germany, October 11, 2001 [http://www.bundeskanzler.de/Regierungserklaerung-.8561.htm].

Bundesregierung (Federal Government of Germany), Regierungserklärung von Bundeskanzler Schröder am 3. April 2003 zur internationalen Lage und den Ergebnissen des Europäischen Rates in Brüssel (April 3, 2003 Statement of Government Policy by Chancellor Schröder about the International State of Affairs and the Results of the European Commission in Brussels). Berlin, Germany, April 3, 2003 [http://www.bundeskanzler.de/Regierung-serklaerung.8561.htm].

Bundeswehr, "Einsatzgebiete der Bundeswehr (Areas of Engagement by the Armed Forces)," [http://www.bundeswehr.de/forces/030728_einsatz_welt.php].

Daalder, Ivo H., “The End of Atlanticism,” Survival, 45, 2:147-166, Summer 2003.

Deckers, Wolfgang, "Germany and the Balkans: Reflections on an Uneasy Relationship,” Journal of Southern Europe and the Balkans, 4, 2:157-170, 2002.

Diehl, Jackson, “Still Losing at Diplomacy,” The Washington Post, September 29, 2003, A19. European Commission, "Iraq and Peace in the World,” Flash Eurobarometer, Public Opinion Survey conducted 8-16 October, 2003 [http://europa.eu.int/comm/public_opinion/flash/fl151_iraq_full_report.pdf], November 2003.

Fischer, Joschka, Speech by Foreign Minister Fischer at the 56th General Assembly of the UN, New York City, NY, November 12, 2001 [http://www.germanyinfo.org/relaunch/politics/speeches/111201.html].

Fischer, Joschka, Speech by Foreign Minister Fischer at the Opening of the Third Conference of Chiefs of Mission, Berlin, Germany, May 27, 2002a

[http://www.auswaertigesamt.de/www/de/infoservice/presse/presse_archiv?archiv_id=3252]. 
Fischer, Joschka, Interview with Foreign Minister Fischer, Die Welt, February 12, 2002b [http://www.welt.de/daten/2002/02/12/0212de313826.htx?print=1].

Fischer, Joschka, Interview with Foreign Minister Fischer, Neue Zürcher Zeitung, April 13, 2003a [http://www.auswaertiges-amt.de/www/de/infoservice/presse/presse_archiv?archiv_id=4342].

Fischer, Joschka, Interview with Foreign Minister Fischer, Die Zeit, 20, May 8, 2003b [http://www.zeit.de/2003/20/J__Fischer].

Fischer, Joschka, Interview with Foreign Minister Fischer, Tagesspiegel, September 11, 2003c [http://www.auswaertiges-amt.de/www/de/infoservice/presse/presse_archiv-?archiv_id=4819].

Fischer, Joschka, Interview with Foreign Minister Fischer, Frankfurter Allgemeine Zeitung, March 17, 2003d [http://www.germany-info.org/relaunch/politics/speeches/031703.htm].

German Marshall Fund of the United States and the Compagnia di San Paolo, “Transatlantic Trends 2003,” Public Opinion Survey, 2003 [http://www.transatlantic-trends.org/].

Gordon, Philip H., “Bridging the Atlantic Divide,” Foreign Affairs, 82, 1:70-83, 2003.

Hanrieder, Wolfram F., Germany, America, Europe: Forty Years of German Foreign Policy. New Haven, CT: Yale University Press, 1989.

Hoagland, Jim, “America the Absent,” The Washington Post, September 6, 2001, A23.

International Institute for Strategic Studies, The Military Balance 1991-1992. London, UK: International

Institute for Strategic Studies, 1991. International Institute for Strategic Studies, The Military Balance 2003-2004. London, UK: International Institute for Strategic Studies, 2003.

Ischinger, Wolfgang, “The Globalization of Justice,” The Washington Post, September 24, 2001, A19.

Ischinger, Wolfgang, Speech by German Ambassador at the Center for Strategic and International Studies, Washington, DC, October 28, 2002

[http://www.germanyinfo.org/relaunch/politics/speeches/102802.htm].

Joffe, Josef, “Weltpolitik ohne Partner (World Politics without Partners),” Die Zeit, 9, 2001a [http://www.zeit.de/archiv/2001/09/200109_2._leiter.xml].

Joffe, Josef, Remarks by Josef Joffe to the Washington Institute for Near East Policy on Europe and the campaign against terror, November 6, 2001b [http://www.washingtoninstitute.org/watch/policywatch/policywatch2001/583.htm]. 
Jones, Alun, The New Germany: A Human Geography. Chichester, UK/ New York, NY: John Wiley and Sons, 1994.

Kagan, Robert, “Power and Weakness,” Policy Review, 113:3-28, June/July 2002.

Kagan, Robert, Of Paradise and Power: America and Europe in the New World Order. New York, NY: Knopf, 2003.

Krieger, Wolfgang, “Toward a Gaullist Germany? Some Lessons From the Yugoslav Crisis,” World Policy Journal, XI, 1:26-38, Spring 1994.

Larres, Klaus, “Mutual Incomprehension: U.S.-German Value Gaps beyond Iraq,” The Washington Quarterly, 26, 2:23-42, 2003.

Melloan, George, “Germany Makes a Choice, and It Isn’t France,” The Wall Street Journal, July 22, 2003, A11.

Ossenbrügge, Jürgen, “Territorial Ideologies in West Germany 1945-1985: Between Nationalist Geopolitics and Regionalist Attitudes,” Political Geography Quarterly, 8, 4:387-399, 1989.

Ó Tuathail, Gearóid, Critical Geopolitics: The Politics of Writing Global Space. Minneapolis, MN: University of Minnesota Press, 1996.

Rau, Johannes, Speech at a demonstration in front of the Brandenburg Gate, Berlin, September 14, 2001 [http://eng.bundespraesident.de/dokumente/Rede/ix_59074.htm].

Ross, Jan, “Falken der Freiheit (Falcons of Freedom),” Die Zeit, 20, 2003 [http://zeus.zeit.de/text/2003/20/Transatlantiker].

Schröder, Gerhard, Speech by Chancellor Gerhard Schröder before the Bundestag, October 11, 2001 [http://www.germany-info.org/relaunch/politics/speeches/101101.html].

Schröder, Gerhard, Speech by Chancellor Gerhard Schröder to the World Economic Forum, New York, February 1, 2002 [http://www.bundeskanzler.de/Reden-.7715.58085/Rede-vonBundeskanzler-Gerhard-Schroeder-beim-Weltwirtschaftsforum.htm].

Schröder, Gerhard, “Germany Will Share the Burden in Iraq,” The New York Times, September 19, 2003a, A27.

Schröder, Gerhard, Speech by Chancellor Schröder to the American Chamber of Commerce in Germany, Berlin, May 9, 2003b [http://www.germany-info.org/relaunch/politics/speeches/030905.htm].

Schröder, Gerhard, Speech by Chancellor Schröder to the General Assembly of the United Nations, New York City, September 24, 2003c 
[http://www.bundeskanzler.de/Reden.7715.531138/Bundeskanzler-Schroeder-vor-derGeneralversammlu/htm].

SIPRI (Stockholm International Peace Research Institute), SIPRI military expenditure database [http://first.sipri.org/non_first/result_milex.php], 2003.

Smith, Neil, American Empire: Roosevelt's Geographer and the Prelude to Globalization. Berkeley and Los Angeles, CA: University of California Press, 2003.

Voigt, Karsten, Interview with Karsten Voigt, Coordinator for German-American Relations in the Foreign Office, on Deutschlandfunk-Radio, November 3, 2003

[http://www.auswaertigesamt.de/www/de/infoservice/presse/presse_archiv?-archiv_id=5031].

Walker, Martin, “Post 9/11: The European Dimension,” World Policy Journal, XVIII, 4:1-10, Winter 2001/2002. 